\title{
Expression of guanylyl cyclase-B (GC-B/NPR2) receptors in normal human fetal pituitaries and human pituitary adenomas implicates a role for C-type natriuretic peptide
}

lain R Thompson ${ }^{1 *}$, Annisa N Chand ${ }^{1 *}$, Peter J King ${ }^{4}$, Olaf Ansorge ${ }^{5}$, Niki Karavitaki ${ }^{6}$, Ceri Alexander Jones ${ }^{4}$, Dolkun Rahmutula ${ }^{8}$, David G Gardner ${ }^{8}$, Vladimir Zivkovic ${ }^{7}$, Caroline $P$ Wheeler-Jones ${ }^{2}$, Imelda M McGonnell ${ }^{3}$, Márta Korbonits ${ }^{4}$, Richard A Anderson ${ }^{9}$, John A H Wass ${ }^{6}$, Alan $S$ McNeilly ${ }^{9}$ and Robert C Fowkes ${ }^{1}$

\footnotetext{
${ }^{1}$ Endocrine Signalling Group, Veterinary Basic Sciences, ${ }^{2}$ Cardiovascular Research Group and ${ }^{3}$ Developmental Biology Research Group, Royal Veterinary College, University of London, Royal College Street, London NW1 OTU, UK

${ }^{4}$ Department of Endocrinology, Barts and the London School of Medicine, Queen Mary University of London, London EC1M 6BQ, UK ${ }^{5}$ Neuropathology Department, John Radcliffe Hospital, Oxford OX3 9DU, UK

${ }^{6}$ Department of Endocrinology, Oxford Centre for Diabetes, Endocrinology and Metabolism, Churchill Hospital, Oxford OX3 7LJ, UK

${ }^{7}$ School of Medicine, Institute of Forensic Medicine, University of Belgrade, 11000 Belgrade, Serbia

${ }^{8}$ Department of Medicine, University of California at San Francisco, San Francisco, California 94143-0540, USA

${ }^{9}$ Medical Research Council Human Reproductive Sciences Unit, The Queen's Medical Research Institute, Centre for Reproductive Biology, Edinburgh EH16 4TJ, UK

(Correspondence should be addressed to R C Fowkes; Email: rfowkes@ @rvc.ac.uk)

*(I R Thompson and A N Chand contributed equally to this work)
}

\begin{abstract}
C-type natriuretic peptide (CNP/Nppc) is expressed at high levels in the anterior pituitary of rats and mice and activates guanylyl cyclase B receptors (GC-B/Npr2) to regulate hormone secretion. Mutations in NPR2/Npr2 can cause achondroplasia, GH deficiency, and female infertility, yet the normal expression profile within the anterior pituitary remains to be established in humans. The current study examined the expression profile and transcriptional regulation of NPR2 and GC-B protein in normal human fetal pituitaries, normal adult pituitaries, and human pituitary adenomas using RT-PCR and immunohistochemistry. Transcriptional regulation of human NPR2 promoter constructs was characterized in anterior pituitary cell lines of gonadotroph, somatolactotroph, and corticotroph origin. NPR2 was detected in all human fetal and adult pituitary samples regardless of age or sex, as well as in all adenoma samples examined regardless of tumor origin. GC-B immunoreactivity was variable in normal pituitary, gonadotrophinomas, and somatotrophinomas. Maximal transcriptional regulation of the NPR2 promoter mapped to a region within $-214 \mathrm{bp}$ upstream of the start site in all anterior pituitary cell lines examined. Electrophoretic mobility shift assays revealed that this region contains Sp1/Sp3 response elements. These data are the first to show NPR2 expression in normal human fetal and adult pituitaries and adenomatous pituitary tissue and suggest a role for these receptors in both pituitary development and oncogenesis, introducing a new target to manipulate these processes in pituitary adenomas.
\end{abstract}

Endocrine-Related Cancer (2012) 19 497-508 


\section{Introduction}

The particulate guanylyl cyclase (GC) receptors mediate the effects of natriuretic peptides, heat-stable enterotoxins, odor, and peptidase activity in a broad range of tissues by increasing the levels of cyclic guanosine $3^{\prime}, 5^{\prime}$-monophosphate (cGMP). GC-A and GC-B are probably the best characterized receptors in this family and act as specific receptors for atrial natriuretic peptide (ANP) and C-type natriuretic peptide (CNP) respectively. GC-B is expressed throughout the body but is present in many endocrine tissues and is widely expressed throughout the CNS (for review see Fowkes \& McArdle (2000) and Potter et al. (2006)). Mice lacking the Npr2 gene, which encodes GC-B, are dwarf due to severe deficiency in the process of endochondral ossification and exhibit early lethality (Tamura et al. 2004). Intriguingly, these mice are also $\mathrm{GH}$ deficient, implicating a potential pituitary phenotype. Mutations in the gene (natriuretic peptide precursor C (Nppc)) encoding CNP essentially phenocopy those in Npr2 (Chusho et al. 2001), but to date, no mutations have been reported in the human $N P P C$ gene. Instead, translocations have been shown to cause overexpression of $N P P C$, resulting in skeletal overgrowth and deformities (Bocciardi et al. 2007, Moncla et al. 2007). However, the role of GC-B receptors, or of $\mathrm{CNP}$, in the anterior pituitary remains poorly understood.

Our previous molecular and pharmacological studies performed on well-established rodent anterior pituitary cell lines (Fowkes et al. 1999, 2000, Thompson et al. 2009) have shown that GC-B signaling is the major pathway used by CNP in most anterior pituitary cell types. Despite this, there is a paucity of data describing the expression of GC-B in human pituitaries and pituitary adenomas. In the current study, we have examined the mRNA expression of $N P R 2$ in a range of human pituitary adenomas and normal human fetal and adult pituitaries, determined the transcriptional regulation of the human GC-B promoter in anterior pituitary cell lines, and established the localization of GC-B protein expression by immunohistochemistry in a range of human pituitary adenomas.

\section{Materials and methods}

\section{Cell culture}

$\alpha \mathrm{T} 3-1, \mathrm{~L} \beta \mathrm{T} 2, \mathrm{GH} 3$, and AtT-20 cells were cultured as described previously (Fowkes et al. 2000, Thompson et al. 2009) using DMEM (Sigma-Aldrich) containing $10 \%$ FCS, penicillin, and streptomycin.

\section{Mouse primary pituitary cell culture}

Pituitaries were removed from 8-week-old random cycling female C57/BL6 mice (20 per experiment) and subjected to enzymatic dispersion as described previously (McArdle \& Poch 1992, Thompson et al. 2009). Dispersed cells were then cultured overnight in 24-well plates before transfection with the indicated $N P R 2$ reporter gene constructs.

\section{RNA extraction from human pituitary tumors and fetal pituitaries}

Human pituitary adenomas were obtained from the Thomas Willis Brain Bank (project ethics reference 07/H0606/85), Department of Neuropathology, John Radcliffe Hospital, Oxford, UK. Tissue was collected immediately at the postoperative stage, snap frozen, and stored at $-80{ }^{\circ} \mathrm{C}$ before extracting total RNA using the Trizol method followed by RNA cleanup and DNase treatment, as described previously (Thompson et al. 2009). Normal human fetal pituitary RNA samples were obtained from fetuses collected following medical termination of pregnancy (between 14 and 18 weeks of gestation), subject to local ethical approval (by the Lothian Paediatrics/Reproductive Medicine Research Ethics Subcommittee) as described previously (Pope et al. 2006). Normal pituitary samples from patients were obtained by autopsy within $6 \mathrm{~h}$ of death (University Clinical Centre, Belgrade, Serbia), as described previously (Butz et al. 2010). These individuals had no evidence of any endocrine disease. All biometric data relating to human samples are summarized in Tables 1, 2 and 3.

\section{RT-PCR analyses of NPR2 and NPPC expression in human pituitary tissue}

Following generation of the first-strand cDNA (Applied Biosystems, Paisley, UK), PCR was performed using components from the Qiagen Taq Core kit and ThermoStart DNA polymerase and buffer kit. The following primer sets were used: NPR2: F, AACGGGCGCATTGTGTATATCTGCGGC and R, TTATCACAGGATGGGTCGTCCAAGTCA; NR5Al: F, GCCAGGAGTTCGTCTGTCTC and R, TCAATGAGAAGGTTGTTGCG; POU1F1: F, TGGAGTGATGGCAGGCAGTTTAA and R, TTTCACCGGTTTTTCTCTCTGCCT; and NPPC: F, CTGCTCACGCTGCTCTCC and R, CCTTCTTGTTGGCTCCTTTG. All PCR was performed between 30 and 35 cycles before analysis of products using $1.6 \%(\mathrm{w} / \mathrm{v})$ agarose gel electrophoresis. 
Table 1 Biometric data and adenoma diagnosis (by IHC) of archived patient samples

\begin{tabular}{llll}
\hline Tumor & Age & Sex & Diagnosis (IHC) \\
\hline 1 & 49 & $\mathrm{M}$ & Gonadotroph \\
2 & 70 & $\mathrm{M}$ & Gonadotroph \\
3 & 49 & $\mathrm{M}$ & Gonadotroph \\
4 & 66 & $\mathrm{M}$ & Gonadotroph \\
5 & 71 & $\mathrm{M}$ & Gonadotroph \\
6 & 74 & $\mathrm{M}$ & Gonadotroph \\
7 & 68 & $\mathrm{M}$ & Gonadotroph \\
8 & 31 & $\mathrm{M}$ & Gonadotroph \\
9 & 60 & $\mathrm{~F}$ & Gonadotroph \\
10 & 68 & $\mathrm{~F}$ & Gonadotroph \\
11 & 65 & $\mathrm{~F}$ & Gonadotroph \\
12 & 65 & $\mathrm{~F}$ & Somatotroph/lactotroph \\
13 & 26 & $\mathrm{~F}$ & Somatotroph \\
14 & 36 & $\mathrm{~F}$ & Somatotroph/lactotroph \\
15 & 58 & $\mathrm{~F}$ & Somatotroph \\
16 & 51 & $\mathrm{M}$ & Somatotroph \\
17 & 39 & $\mathrm{~F}$ & Null \\
18 & 45 & $\mathrm{M}$ & Null \\
19 & 67 & $\mathrm{~F}$ & Corticotroph \\
20 & 48 & $\mathrm{M}$ & Corticotroph \\
\hline
\end{tabular}

\section{Immunohistochemistry for GC-B}

Human gonadotroph and somatotroph adenoma paraffinfixed samples were sectioned to $4 \mu \mathrm{m}$ for analysis. Paraffin embedding was removed with Histoclear before subjecting the sections to antigen retrieval and immunohistochemistry for GC-B using a rabbit polyclonal antibody (Abcam, Cambridge, UK) according to the standard protocols described previously (Suliman et al. 2007). All slides were immersed in hematoxylin counterstain, washed, dehydrated, and then mounted on distrene-plasticizer-xylene before examination using a Leica microscope.

\section{Bioinformatic analyses of transcription factor response elements in the human NPR2 promoter}

The human NPR2 promoter sequence (accession number AY528561) was analyzed using two online databases, PATCH (http://www.gene-regulation.com/ cgi-bin/pub/programs/patch/bin/patch.cgi) and WWW Promoter Scan (http://www-bimas.cit.nih.gov/molbio/ proscan/index.html).

\section{Plasmids and transient transfection studies}

The reporter constructs encoding the human NPR2 promoter have been described previously (Rahmutula et al. 2004). All constructs were verified for orientation and correct sequence by restriction endonuclease digests. Large-scale preparation and purification of plasmids was performed by alkaline lysis and resin purification (Qiagen Ltd). For transfections, $3 \times 10^{5}$ cells/well were plated in 24-well plates and transfected using Lipofectin (Invitrogen) with $1.25 \mu \mathrm{g} /$ well of each reporter construct along with $0.5 \mu \mathrm{g} /$ well BosGal, and protein extracts were assayed for reporter gene activity as described previously (Thompson et al. 2009). The data shown were normalized for protein content using a Nanodrop (ND1000, Thermo Scientific, Loughborough, UK).

\section{Nuclear protein extraction and electrophoretic mobility shift assay}

Nuclear protein extracts were prepared from $1 \times 10^{6}$ GH3 or L $\beta$ T2 cells using a modification of a method described previously (Schreiber et al. 1989, Thompson et al. 2009). Probes were created by filling in the 5 '-AGCT overhangs of the annealed NPR2 oligonucleotides with Klenow polymerase, and EMSAs were performed as described previously (Thompson et al. 2009). The following primer sets were used: NPR2-PROX: F, AGCTCAGCGGGGGAGGGGCGGGGGCGGGCGGCCT and R, AGCTAGGCCGCCCGCCCCCGCCCCTCCCCCGCTG; NPR2-MID: F, AG$C T C G C C G G A G G G T G G G G C C G G G A$ and R, $A G$ CTTCCCGGCCCCACCCTCCGGCG; NPR2-DIST: $\mathrm{F}$, AGCTGCGCCCGGGTGGGGGGTGGGG and R, AGCTCCCCACCCCCCACCCGGGCGC.

For gel shifts, $2 \mu \mathrm{l} \mathrm{Sp1}$ or Sp3 antibodies (Santa Cruz Biotechnology, Santa Cruz, CA, USA) were added to the reaction to identify the components of the specific protein complexes, and these samples were incubated on ice for $60 \mathrm{~min}$. The reactions were then incubated for $15 \mathrm{~min}$ at $30{ }^{\circ} \mathrm{C}$ in the presence of $1 \mathrm{ng}$ probe. Complexes were electrophoresed on a $5 \%$ native acrylamide gel, dried, and visualized by autoradiography.

\section{Statistical analysis and data presentation}

For reporter gene activities in pituitary cell lines, the data shown were normalized and pooled to represent the mean \pm s.E.M. of at least four independent

Table 2 Biometric data of human fetal pituitary samples

\begin{tabular}{lll}
\hline Sample & $\begin{array}{l}\text { Age at termination } \\
\text { (weeks/days) }\end{array}$ & Sex \\
\hline 1 & $16 \mathrm{w} / 3 \mathrm{~d}$ & $\mathrm{M}$ \\
2 & $14 \mathrm{w} / 4 \mathrm{~d}$ & $\mathrm{~F}$ \\
3 & $18 \mathrm{w} / 6 \mathrm{~d}$ & $\mathrm{~F}$ \\
4 & $16 \mathrm{w} / 6 \mathrm{~d}$ & $\mathrm{M}$ \\
5 & $14 \mathrm{w} / 6 \mathrm{~d}$ & $\mathrm{M}$ \\
6 & $19 \mathrm{w} / 4 \mathrm{~d}$ & $\mathrm{~F}$ \\
7 & $15 \mathrm{w}$ & $\mathrm{F}$ \\
8 & $19 \mathrm{w} / 3 \mathrm{~d}$ & $\mathrm{~F}$ \\
\hline
\end{tabular}


Table 3 Biometric data of normal adult pituitary samples

\begin{tabular}{lccl}
\hline Sample & Age & Sex & Cause of death \\
\hline 1 & 37 & M & Road traffic accident \\
2 & 19 & F & Road traffic accident \\
3 & 72 & M & Myocardial infarction \\
4 & 68 & M & Cerebral hemorrhage \\
\hline
\end{tabular}

experiments, each performed in triplicate. The reporter gene assays in primary mouse pituitary cells represent the mean \pm s.E.M. of four individual transfections. Numerical data were subjected to ANOVA and were followed, where appropriate, by Bonferonni's multiple comparisons test, accepting $P<0.05$ as significant, using inbuilt equations in GraphPad Prism 5.0 (GraphPad, San Diego, CA, USA).

\section{Results}

\section{Expression of NPR2 and NPPC in normal human fetal and adult pituitaries}

Having recently established that mouse pituitaries and gonadotroph cell lines of different developmental origin expressed most components of an intact natriuretic peptide system (Thompson et al. 2009), we initially examined a series of normal human fetal pituitary samples for the expression of NPR2 and $N P P C$ transcripts. RNA was extracted from eight normal human fetal pituitaries and four normal adult pituitaries. As shown in Fig. 1A, NPR2 and NPPC transcripts were detected in all fetal pituitary samples, regardless of age or sex. Expression of POU1F1 (encoding Pit-1) and NR5Al (encoding SF-1) was also detected in all fetal samples. Similarly, NPR2 and POU1F1 transcripts were also detected in all the normal adult pituitary samples (Fig. 1B). Interestingly, $N P P C$ transcripts were detected in 3/4 normal pituitary samples, and NR5Al being detected in $2 / 4$ normal pituitary samples. Collectively, these data suggest that $N P R 2$ and NPPC are expressed in both developing and adult human anterior pituitary tissues.

\section{Expression of NPR2 in human pituitary adenomas}

We broadened our investigations to determine the expression of $N P P C$ and $N P R 2$ in human pituitary adenomas. RT-PCR was performed on RNA samples extracted from a range of tumors. As shown in Fig. 2A, all pituitary tumors of gonadotroph origin expressed $N P R 2$, and for those in which sufficient cDNA remained, NPPC transcripts were also detected (tumors 3-8). As expected, all these tumors expressed the gonadotroph-specific marker, NR5A1. Interestingly, POU1F1 transcripts were detected in the majority of these gonadotroph origin tumors, albeit at variable intensity. Identical RT-PCR screens were performed on RNA extracted from somatotrophinomas (Fig. 2B) as well as null cell adenomas, silent ACTH tumors, and a normal pituitary sample (Fig. 2C). Again, all samples examined expressed NPR2 transcripts, and where sufficient cDNA remained, NPPC transcripts were also detected (tumors 12-15). Expression of NR5AI and POU1F1 was absent in the two corticotroph tumors, whereas both null cell adenomas expressed POU1F1, but only one expressed NR5A1. In keeping with previous studies, some somatotrophinomas expressed NR5Al transcripts (Aylwin et al. 2001). These studies represent the first description of NPR2 and NPPC transcripts in a range of human pituitary adenomas.

\section{Detection of GC-B immunoreactivity in human pituitary adenomas}

Having established that NPR2 is expressed in all pituitary adenoma samples examined and in human fetal pituitaries, we next examined whether GC-B protein could be detected in tissue from some of the adenoma samples analyzed previously.

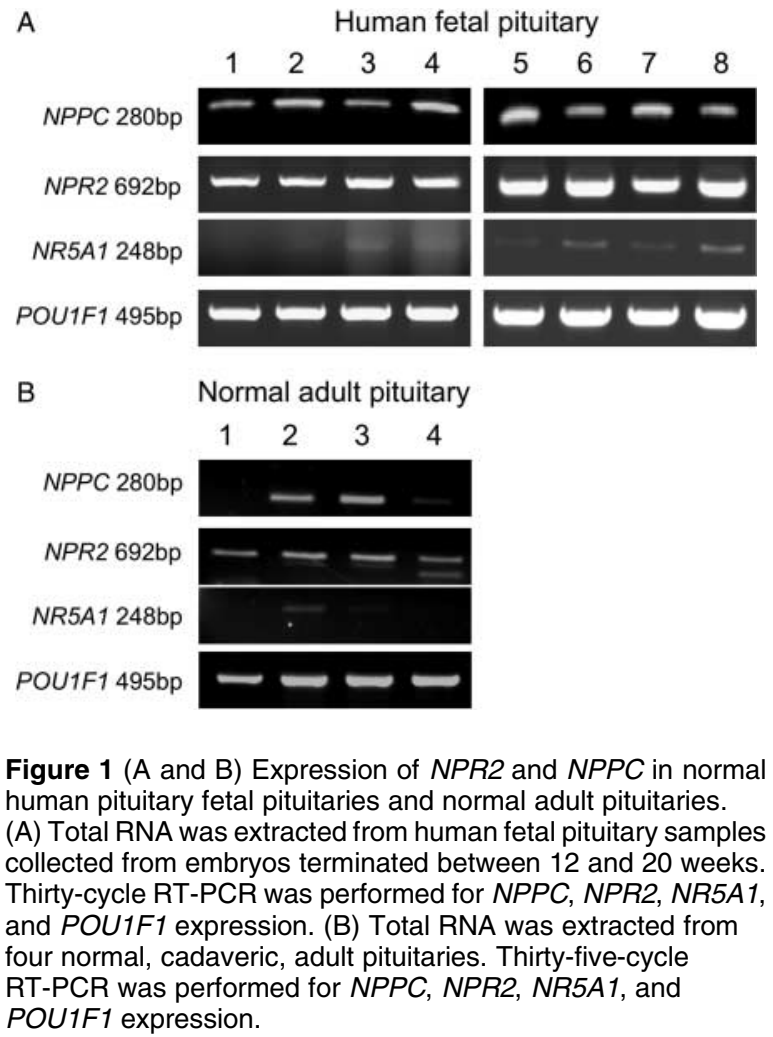


A

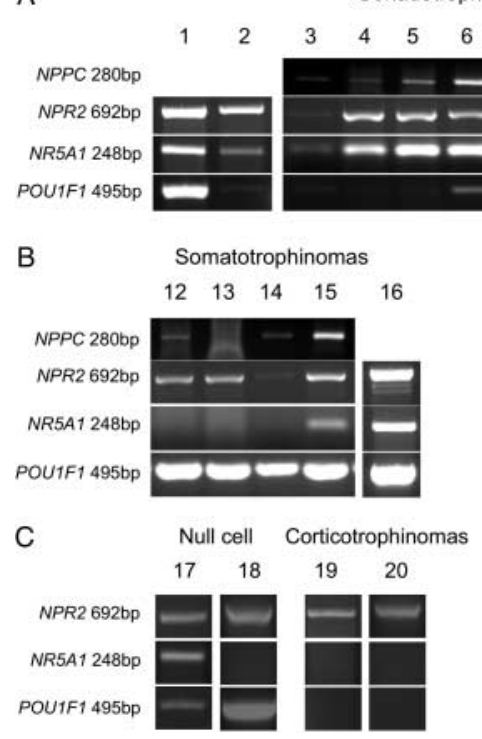

Figure 2 ( $\mathrm{A}, \mathrm{B}$ and $\mathrm{C})$ Expression of $N P R 2$ and $N P P C$ in a range of human pituitary adenomas. RT-PCR was performed over 30 cycles using NPR2- and NPPC-specific primers in gonadotrophinomas $(A)$, somatotrophinomas $(B)$, or other pituitary tumor types (C). As a control, the expression of the gonadotroph-specific transcription factor $N R 5 A 1$, as well as POU1F1, was also performed.

Immunohistochemistry was performed for GC-B immunoreactivity (GC-B-ir) in a range of sections taken from some of the gonadotrophinoma and somatotrophinoma samples characterized for the molecular expression analyses. Initial optimization studies were performed on tissues known to express GC-B protein, and specific GC-B-ir was detected in mouse Purkinje cells of the cerebellum and posterior pituitary tissue (Fig. 3A), as described previously (Herman et al. 1996, Müller et al. 2009). Normal adult human pituitary tissue also revealed specific GC-B-ir (Fig. 3B). These optimized conditions were used on the human pituitary adenoma samples, and, GC-B-ir was detected in the gonadotrophinomas (Fig. 3C) and somatotrophinomas (Fig. 3D) examined, although the intensity of the apparent GC-B expression was variable. These data suggest that GC-B protein is also expressed in human pituitary adenomas and normal human pituitary tissue.

\section{Transcriptional regulation of the human NPR2 promoter in anterior pituitary cell lines}

The expression profile of NPR2 in both normal and adenomatous human pituitary tissue, regardless of cellular origin, suggested that the control of NPR2 expression in all anterior pituitary cell types might share a common mechanism. To examine whether celltype-specific regulation of the NPR2 promoter could occur, we transiently transfected well-established pituitary tumor cell lines representative of gonadotrophs ( $\alpha \mathrm{T} 3-1$ and L $\beta \mathrm{T} 2)$, somatolactotrophs (GH3), and corticotrophs (AtT-20) with a series of human NPR2 promoter deletion constructs, as described previously (Rahmutula et al. 2004). Promoter activity was determined after $24 \mathrm{~h}$ by reporter gene assays.

\section{Gonadotroph cell lines}

The promoter was active in both early- ( $\alpha \mathrm{T} 3-1, \mathrm{Cga}$ expressing) and later-stage (L $\beta \mathrm{T} 2, C g a, L h b$, and Fshb expressing) gonadotrophs (see Fig. 4), and in both cell lines, the most proximal $-214 \mathrm{bp}$ of the human $N P R 2$ promoter was sufficient to drive maximal reporter gene activity (to $7.9 \pm 1.8$-fold $(P<0.001)$ and 3.2 \pm 0.2 -fold $(P<0.05)$ in $\alpha \mathrm{T} 3-1$ and L $\beta$ T2 cells respectively). Furthermore, in L $\beta$ T2 cells, but not in $\alpha \mathrm{T} 3-1$ cells, the -645 construct also showed maximal activity (3.6 \pm 0.8 -fold, $P<0.01)$, suggesting that additional transcriptional activity is switched on during the process of gonadotroph development.

\section{Somatolactotroph and corticotroph cell lines}

As shown in Fig. 4, the NPR2 reporter gene constructs were active in both GH3 ( $\mathrm{Gh}$ and $\mathrm{Prl}$ expressing) and AtT-20 (Pomc expressing) cells, with the -214 construct driving maximal transcriptional activity (to $7.8 \pm 1.3$-fold $(P<0.001)$ and $2.9 \pm 0.5$-fold $(P<0.01)$, in GH3 and AtT-20 cells respectively). Finally, to determine whether the most active NPR2 promoter constructs could also function in nonimmortalized cells, similar transfections were performed in cultures of mouse pituitary cells. As shown in Fig. 4E, the -214 and -441 constructs showed significant transcriptional activity compared with pGL3LUC (to $13.5 \pm 3.1$-fold $(* P<0.05)$ and 15.3 \pm 2.8 -fold $(* * P<0.01)$ respectively). Collectively, these data suggest that sequences residing within this region regulate basal expression of $N P R 2$ and that this is common to all anterior pituitary cell types.

\section{Molecular characterization of the proximal human NPR2 promoter}

The reporter gene assay data suggested that $-214 \mathrm{bp}$ of the proximal human NPR2 promoter was sufficient for maximal basal promoter activity (see Fig. 4A, B, C, $\mathrm{D}$ and $\mathrm{E}$ ). We further characterized the region between -135 and -214 , initially through a bioinformatic screen to establish the presence of relevant 
A

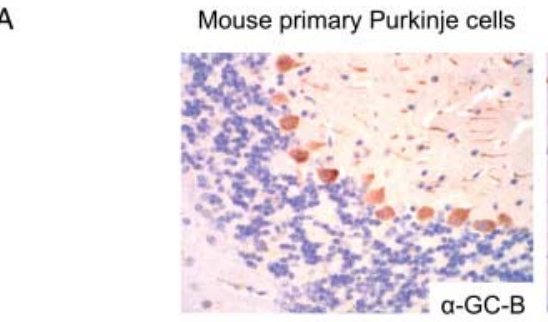

Mouse posterior pituitary cells

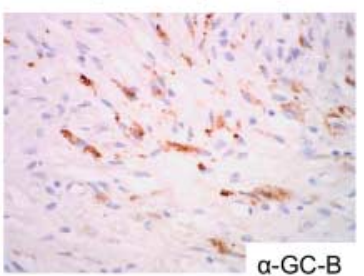

B

Normal human pituitary
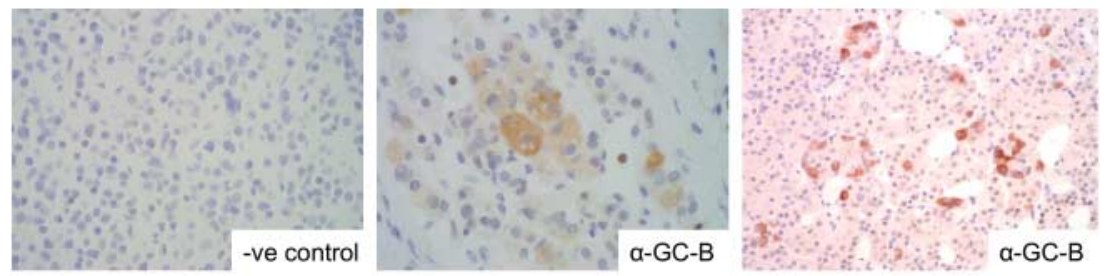

C

Gonadotrophinomas
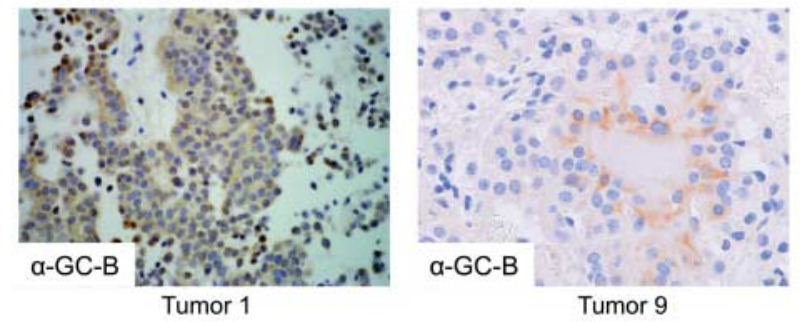

D

Somatotrophinomas
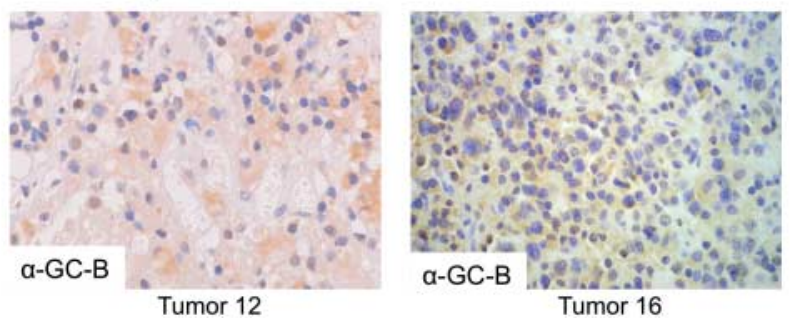

Figure 3 (A, B, C and D) Detection of GC-B immunoreactivity (GC-B-ir) in human pituitary gonadotrophinomas and somatotrophinomas. (A) Optimization images of GC-B-ir in mouse primary Purkinje cells (left) and posterior pituitary cells (right). (B) GC-B-ir in two independent normal human pituitary samples. The negative control slide was generated without incubation with primary antibody. (C and D) GC-B-ir in sections of gonadotrophinomas (tumors 1, 9) and somatotrophinomas (tumors 12, 16). The brown staining indicates GC-B-ir, and the blue/purple is hematoxylin counterstain. All images were taken at either $20 \times$ or $40 \times$ magnification.

transcription factor binding sites. As no cell-typespecific promoter activity had been detected (Fig. 4), we were particularly interested in ubiquitously expressed transcription factors that have previously been implicated in the transcriptional control of the $N P R 2$ promoter, namely members of the specificity protein family (Rahmutula et al. 2004). As shown in Fig. 5A, numerous consensus Sp1/Sp3 binding sites were found in this proximal promoter region. We subdivided these GC-rich 'hotspots' into proximal (prox), middle (mid), and distal (dist) regions and generated ${ }^{32} \mathrm{P}$-labeled probes to perform EMSA analyses. As shown in Fig. 5B, all the three NPR2 probes (prox, mid, and dist) formed complexes with nuclear extracts from GH3 and L $\beta$ T2 cells. Each of these regions was capable of competing for protein complexes, as excess unlabeled prox, mid, and dist annealed oligonucleotides successfully competed for ${ }^{32} \mathrm{P}$-labeled prox probe (Fig. 5C). However, it was clear from these initial EMSAs that the prox and mid regions of the NPR2 promoter yielded the more intense complex formation. Therefore, subsequent supershift experiments were performed using these two probes only. As shown in Fig. 5D and E, the presence of Sp1 

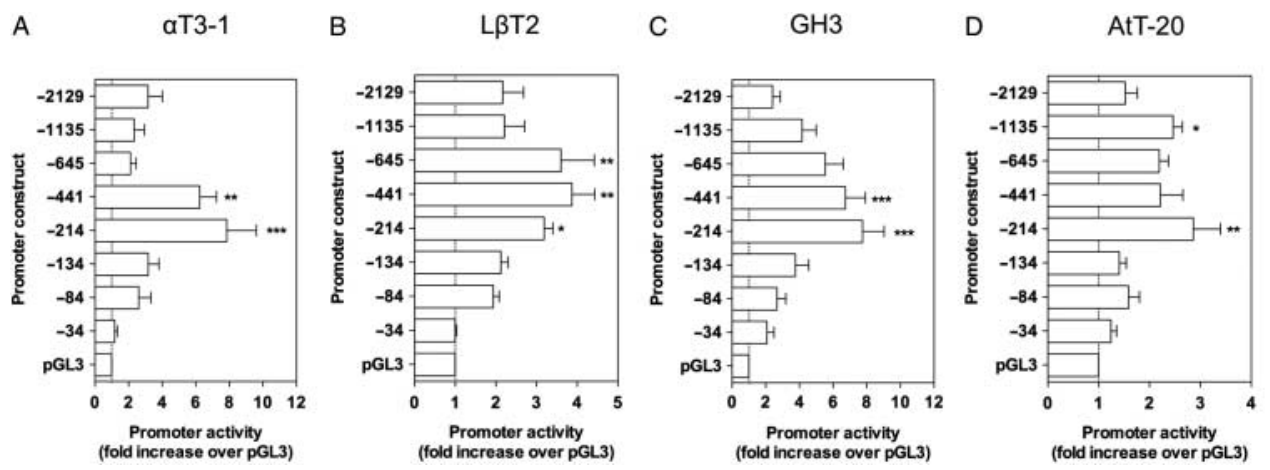

E Mouse pituitary cells

Figure 4 (A, B, C, D and E) Transcriptional regulation of the human NPR2 promoter in rodent anterior pituitary tumor cell lines and mouse primary pituitary cells. A series of deletion constructs encoding the human NPR2 promoter were transiently transfected into (A) $\alpha \mathrm{T} 3-1,(\mathrm{~B}) \mathrm{L} \beta \mathrm{T} 2$ (gonadotrophs), (C) GH3 (somatolactotrophs), and (D) AtT-20 (corticotrophs) and left for $24 \mathrm{~h}$. The data shown are pooled from at least four independent experiments, each performed in triplicate and expressed as mean \pm s.E.M., normalized as fold increase over promoterless control (pGL3LUC). ${ }^{\star} P<0.05,{ }^{\star \star} P<0.01,{ }^{\star \star *} P<0.001$, significantly different from pGL3LUC.

(E) Similar transfections were performed using dispersed primary mouse pituitary cells. The data shown are pooled from four individual transfections and expressed as mean \pm S.E.M., normalized as fold increase over promoterless control (pGL3LUC). ${ }^{\star} P<0.05,{ }^{* *} P<0.01$, significantly different from pGL3LUC.

and Sp3 antibodies in the incubation reaction resulted in either a reduction and/or supershift of complexes formed by the interaction of nuclear extracts with prox and mid probes. Collectively, these data reveal that $\mathrm{Sp} 1$ and Sp3 proteins, acting either as homo- or heterodimers, form complexes with the human NPR2 promoter that may regulate basal gene transcription in pituitary cells.

\section{Discussion}

Many previous studies have established the presence of the CNP and its receptor, GC-B, in rat, mouse, and sheep pituitaries (Komatsu et al. 1991, Konrad et al. 1992, Minamino et al. 1993, Yandle et al. 1993, McArdle et al. 1994, Herman et al. 1996, Thompson et al. 2009), yet the expression of GC-B in human pituitary tissue has not been reported. We show for the first time that NPR2 expression is found in normal human fetal pituitary samples, ranging from 12 to 20 weeks of gestation, suggesting that natriuretic peptide signaling is required during pituitary development in humans. In addition, the presence of NPR2 transcripts in normal adult pituitary tissue would support a role for GC-B signaling in later life as well. Furthermore, using a selection of human pituitary adenomas, NPR2 expression was detected at both the mRNA and protein level, regardless of the cellular origin of the tumor.

Our present studies, combining RT-PCR, reporter gene assays, and immunohistochemistry, convincingly show that NPR2 is expressed in a broad range of both normal, developing fetal and adult pituitaries and human pituitary adenomas of different cellular origin. The presence of $N P R 2$ transcripts in tumors of multiple anterior pituitary cell lineages again supports our previous studies that showed potent CNP-stimulated cGMP accumulation occurs in immortalized anterior pituitary cell lines of all origins (Fowkes et al. 2000, Thompson et al. 2009). It is clear that natriuretic peptide signaling is likely to be responsible for significant production of cGMP in the human anterior pituitary. Whether gonadotroph cells are the major source of CNP-stimulated cGMP in the pituitary, as we have shown in rat and mouse pituitaries and cell lines (Fowkes et al. 2000, Thompson et al. 2009), remains to be established.

The detection of NPPC transcripts are the first to document the developmental expression in human pituitaries and suggest that, along with $N P R 2, \mathrm{CNP}$ is involved in the local regulation of the developing anterior pituitary gland. Furthermore, we were also able to detect NPPC transcripts in gonadotrophinoma and somatotrophinoma samples and in three of the four normal human pituitary samples (Figs 1 and 2A, B). The relatively variable expression of the NPPC transcripts might indicate an mRNA stability issue of the NPPC gene in archival tissue, and in this regard, highly conserved $3^{\prime}$-untranslated regions have been identified in the $n p p c$ gene of several elasmobranch species that are associated with mRNA stability and translational efficiency (Hyodo et al. 2006). However, it is also possible that NPPC is expressed in a cell-typespecific manner in the pituitary as we, and others, have reported previously in rodents (McArdle et al. 1993, Thompson et al. 2009), and the variable expression in the current study is merely a reflection of the relative contribution of those cell types in each of the tumor or normal pituitary samples examined. 

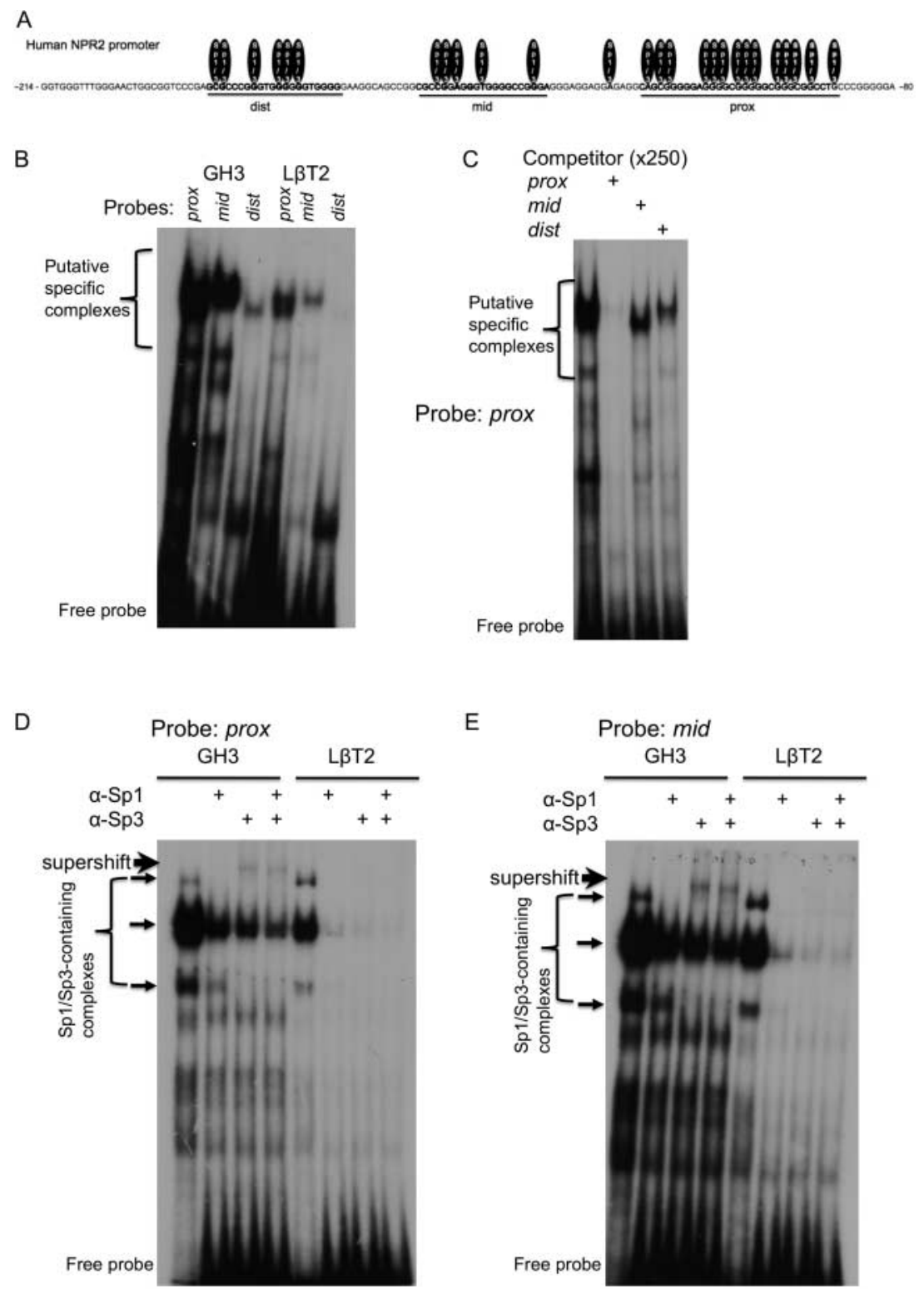

Figure 5 (A, B, C, D and E) Molecular characterization of the proximal human NPR2 promoter. (A) Bioinformatic screening of the human NPR2 promoter revealed the presence of numerous, consensus Sp1 and Sp3 binding throughout the proximal 214 bp of the promoter. Three areas of this region were identified for further characterization by EMSA analysis (prox, mid, and dist). (B) EMSA analyses using nuclear extracts from GH3 and L $\beta$ T2 cells, and three probes encoding the prox, mid, and dist regions of the NPR2 promoter. (C) Competitor assay using excess unlabeled prox, mid, and dist oligonucleotides to compete specific binding to the prox probe, in the presence of GH3 nuclear extracts. (D and E) Supershift assays, using Sp1 and Sp3 antibodies to identify the putative specific protein complexes detected by EMSA in the presence of either the prox (D) or mid (E) probes. The data shown are representative of at least two such experiments.

The factors regulating the expression of $N P R 2$ are still not fully defined. Initial cloning and molecular characterization studies on the human NPR2 promoter in rat aortic smooth muscle cells uncovered a requirement of $\mathrm{Sp} 1$ factors in controlling NPR2 transcription (Rahmutula et al. 2004). Our current studies reveal that an NPR2 promoter construct containing only $214 \mathrm{bp}$ of the proximal promoter is sufficient to drive maximal promoter activity, in keeping with the previous pattern of promoter activity reported in rat aortic smooth muscle cells (Rahmutula et al. 2004). There are numerous Sp1/Sp3 response elements within this region of the human promoter (see Fig. 5A), so it is likely that $\mathrm{Sp} 1$ family proteins are 
also major regulators of $N P R 2$ expression in pituitary tissue. Sp1 is ubiquitously expressed and has been implicated in the regulation of gonadotroph-specific genes (Kaiser et al. 2000, Weck et al. 2000, Bachir et al. 2003, Thompson et al. 2009). As the profile of $N P R 2$ transcriptional activity remained comparable in all cell lines investigated in our study, this suggests that any potential role of $\mathrm{Sp} 1$ in the control of NPR2 expression is common to all pituitary cell lineages and is unlikely to contribute to any cell-type-specific expression of NPR2. Our detailed EMSA analyses, using nuclear protein extracts from GH3 and L $\beta$ T2 cells, revealed complexes indicative of $\mathrm{Sp} 1 / \mathrm{Sp} 3$ homo- and heterodimers, strongly implicating these transcription factors in the basal regulation of NPR2 transcription. However, while the use of pituitary tumor-derived cell lines is informative in demonstrating that endogenous $\mathrm{Sp} 1 / \mathrm{Sp} 3$ proteins can bind to the proximal NPR2 promoter, further investigations are required to establish whether these GC-rich elements of the NPR2 promoter are important in vivo. Nevertheless, previous transcriptional studies on the NPR2 promoter in rat aortic smooth muscle cells showed that mutation of these putative $\mathrm{Sp} 1 / \mathrm{Sp} 3$ binding sites results in up to $90 \%$ inhibition of basal promoter activity, whereas overexpression of exogenous $\mathrm{Sp} 1$ or Sp3 protein can activate $N P R 2$ promoter activity (Rahmutula et al. 2004), clearly supporting a role for $\mathrm{Sp} 1 / \mathrm{Sp} 3$ proteins in the expression of human GC-B receptor.

While we acknowledge that $\mathrm{Sp} 1$ family proteins are ubiquitous, it is interesting to note that $\mathrm{Sp} 1$ is involved in the transcriptional regulation of other members of the natriuretic peptide/GC/cGMP signaling pathway. Both the promoters for ANP (NPPA) and the GC-A receptor $(N P R l)$ have been shown to be regulated by Sp1 (Liang et al. 1999, Kumar et al. 2010, Hu et al. 2011), and we, and others, have indicated a role for $\mathrm{Sp} 1 / \mathrm{Sp} 3$ in controlling Nppc transcription in pituitary cell lines (Ohta et al. 1993, Thompson et al. 2009). The other major regulator of cGMP signaling is the gaseous neurotransmitter, nitric oxide (NO), and both neuronal and endothelial forms of the NO-synthesizing enzyme, NO synthase (NOS1 and NOS3, respectively), are transcriptionally controlled by $\mathrm{Sp} 1$ (Kleinert et al. 1998, Bachir et al. 2003). Finally, the promoters for the cGMP-selective phosphodiesterase 5 enzyme genes (PDE5A1 and PDE5A2) have also been shown to contain Sp1 response elements (Yanaka et al. 1998, Kotera et al. 1999). Collectively, it appears that transcriptional control of proteins involved in cGMP signaling is heavily influenced by Sp1 family proteins.

While the predominant regulatory region involved in controlling NPR2 transcription appears to reside within the most proximal $214 \mathrm{bp}$, our current findings demonstrate some differential regulation of the human NPR2 promoter in gonadotroph cell lines. The -645 bp promoter was also maximally active in L $\beta T 2$ cells, whereas activity of this construct in the developmentally immature $\alpha \mathrm{T} 3-1$ cells was not significant. In silico analysis of this region of the human NPR2 promoter reveals numerous putative response elements for nuclear hormone receptors (e.g. for glucocorticoids, estrogen, and retinoic acid). It remains to be established whether responsiveness to these hormones is enhanced in the more mature gonadotroph to subsequently alter NPR2 transcription.

Expression of natriuretic peptide receptors has previously been shown in tumors of other cellular origin. The GC-A receptor, encoded by NPRl/Nprl, is highly expressed in prostate cancer cells (Wang et al. 2011), and natriuretic peptides have been demonstrated to act as anticancer therapies to treat pancreatic, breast, and lung carcinomas implanted within athymic mice (Vesely 2009). Our demonstration that pituitary tumor tissue also expresses NPR2/GC-B raises the intriguing possibility that these receptors might be useful in generating novel therapies, although pituitary adenomas are usually slow growing and rarely malignant (Melmed 2003). It remains to be established whether GC-B receptors in human pituitary tissue can act as secretagogue modulators, although previous studies suggest that both CNP and NO are capable of stimulating GH secretion from rodent pituitaries (Shimekake et al. 1994), human fetal pituitaries, and human pituitary adenomas (Rubinek et al. 2005).

While there are some reports on pituitary roles for natriuretic peptide signaling, such as increasing GH secretion (Hartt et al. 1995, Shimekake et al. 1994, Eckert et al. 2003) or inhibiting ACTH secretion (Guild \& Cramb 1999), these effects may well be celltype specific and are not known to be recapitulated in humans. Genetically manipulated mouse models of disrupted Nppc or Npr2 also point to a pituitary role for CNP and GC-B (Chusho et al. 2001, Tamura et al. 2004), given the profound growth and reproductive disruption to these animals, yet these intriguing possibilities remain to be determined within a pituitary-specific context. Our current observations of $N P R 2$ expression in all endocrine cell types of the human anterior pituitary support previous suggestions that CNP acts as an autocrine or paracrine regulator in the pituitary, but the nature of this paracrinicity is unknown (Denef 2008). Although the presence of a pituitary natriuretic peptide system in other vertebrate species suggests that cGMP signaling is important for normal pituitary function, understanding of whether a 
similar system is present in human pituitaries is very limited. Before our current observations of pituitary $N P P C$ and NPR2 expression, previous studies on humans suggest that normal pituitary tissue expresses $N P P B$ (encoding BNP), PRKG2 (encoding protein kinase G II), and PDE11A (encoding phosphodiesterase 11A) (Gerbes et al. 1994, Fawcett et al. 2000, Zhan \& Desiderio 2004). The presence of both PKG2 and $P D E 11 A$ in human pituitaries indicates potential cGMP-target proteins, which might regulate the effects of CNP/GC-B signaling. PDE11A acts as a dualspecificity cyclic nucleotide phosphodiesterase that causes cAMP and cGMP hydrolysis (Francis et al. 2011) and, intriguingly, mutations within PRDIIA are associated with several endocrine neoplasias (Horvath et al. 2006, 2009). It is, therefore, feasible that a pituitary natriuretic peptide system in humans might serve to regulate cyclic nucleotide-regulated hormone secretion. Alternatively, as CNP and GC-B are major local regulators of the cardiovasculature, it is tempting to speculate that NPR2 expression is contributing to the local dynamic control of pituitary blood flow, in both normal and adenomatous tissue, given the highly vascularized properties of the anterior pituitary (Turner et al. 2000). It is clear that understanding the physiological relevance of our expression studies within human pituitary tissue remains to be established.

\section{Declaration of interest}

The authors declare that there is no conflict of interest that could be perceived as prejudicing the impartiality of the research reported.

\section{Funding}

This study was supported in part by a post-graduate studentships from the Royal Veterinary College (to support I R Thompson and A N Chand), a BBSRC Project grant BBD0015601 (to R C Fowkes), and a Society for Endocrinology Lab visit grant (to I R Thompson). O Ansorge is supported by the NIHR Oxford Biomedical Research Centre.

\section{Acknowledgements}

$\alpha$ T3-1 and L $\beta$ T2 cells were kindly provided by Prof. P Mellon (UCSD, CA, USA), whereas GH3 and AtT-20 cells were kind gifts from Prof. J M Burrin (WHRI, QMUL, UK) and Prof. J C Buckingham (Imperial College London, UK) respectively. Mouse pituitaries were kindly provided by Prof. I M Sheldon (RVC).

\section{References}

Aylwin SJ, Welch JP, Davey CL, Geddes JF, Wood DF, Besser GM, Grossman AB, Monson JP \& Burrin JM 2001 The relationship between steroidogenic factor 1 and DAX-1 expression and in vitro gonadotropin secretion in human pituitary adenomas. Journal of Clinical Endocrinology and Metabolism 86 2476-2483. (doi:10.1210/ jc.86.6.2476)

Bachir LK, Garrel G, Lozach A, Laverrière JN \& Counis R 2003 The rat pituitary promoter of the neuronal nitric oxide synthase gene contains an Sp1-, LIM homeodomain-dependent enhancer and a distinct bipartite gonadotropin-releasing hormone-responsive region. Endocrinology 144 3995-4007. (doi:10.1210/ en.2002-0183)

Bocciardi R, Giorda R, Buttgereit J, Gimelli S, Divizia MT, Beri S, Garofalo S, Tavella S, Lerone M, Zuffardi O et al. 2007 Overexpression of the C-type natriuretic peptide (CNP) is associated with overgrowth and bone anomalies in an individual with balanced $\mathrm{t}(2 ; 7)$ translocation. Human Mutation 28 724-731. (doi:10.1002/humu.20511)

Butz H, Likó I, Czirják S, Igaz P, Khan MM, Zivkovic V, Bálint K, Korbonits M, Rácz K \& Patócs A 2010 Down-regulation of Wee1 kinase by a specific subset of microRNA in human sporadic pituitary adenomas. Journal of Clinical Endocrinology and Metabolism 95 E181-E191. (doi:10.1210/jc.2010-0581)

Chusho H, Tamura N, Ogawa Y, Yasoda A, Suda M, Miyazawa T, Nakamura K, Nakao K, Kurihara T, Komatsu Y et al. 2001 Dwarfism and early death in mice lacking C-type natriuretic peptide. PNAS 98 4016-4021. (doi:10.1073/pnas.071389098)

Denef C 2008 Paracrinicity: the story of 30 years of cellular pituitary crosstalk. Journal of Neuroendocrinology 20 1-70. (doi:10.1111/j.1365-2826.2008.01676.x)

Eckert SM, Hirano T, Leedom TA, Takei Y \& Gordon Grau E 2003 Effects of angiotensin II and natriuretic peptides of the eel on prolactin and growth hormone release in the tilapia, Oreochromis mossambicus. General and Comparative Endocrinology 130 333-339. (doi:10.1016/S0016-6480 (02)00630-5)

Fawcett L, Baxendale R, Stacey P, McGrouther C, Harrow I, Soderling S, Hetman J, Beavo JA \& Phillips SC 2000 Molecular cloning and characterization of a distinct human phosphodiesterase gene family: PDE11A. PNAS 97 3702-3707. (doi:10.1073/pnas.050585197)

Fowkes RC \& McArdle CA 2000 C-type natriuretic peptide: an important neuroendocrine regulator? Trends in Endocrinology and Metabolism 11 333-338. (doi:10.1016/S1043-2760(00)00288-5)

Fowkes RC, Forrest-Owen W, Williams B \& McArdle CA 1999 C-type natriuretic peptide (CNP) effects on intracellular calcium $\left[\mathrm{Ca}^{2+}\right]_{\mathrm{i}}$ in mouse gonadotropederived $\alpha$ T3-1 cell line. Regulatory Peptides 84 43-49. (doi:10.1016/S0167-0115(99)00066-X)

Fowkes RC, Forrest-Owen W \& McArdle CA 2000 C-type natriuretic peptide (CNP) effects in anterior pituitary cell 
lines: evidence for homologous desensitisation of CNPstimulated cGMP accumulation in $\alpha \mathrm{T} 3-1$ gonadotrophderived cells. Journal of Endocrinology 166 195-203. (doi:10.1677/joe.0.1660195)

Francis SH, Blount MA \& Corbin JD 2011 Mammalian cyclic nucleotide phosphodiesterases: molecular mechanisms and physiological functions. Physiological Reviews 91 651-690. (doi:10.1152/physrev.00030.2010)

Gerbes AL, Dagnino L, Nguyen T \& Nemer M 1994 Transcription of brain natriuretic peptide and atrial natriuretic peptide genes in human tissues. Journal of Clinical Endocrinology and Metabolism 78 1307-1311. (doi:10.1210/jc.78.6.1307)

Guild SB \& Cramb G 1999 Characterisation of the effects of natriuretic peptides upon ACTH secretion from the mouse pituitary. Molecular and Cellular Endocrinology 152 11-19. (doi:10.1016/S0303-7207(99)00068-4)

Hartt DJ, Ogiwara T, Ho AK \& Chik CL 1995 Cyclic GMP stimulates growth hormone release in rat anterior pituitary cells. Biochemical and Biophysical Research Communications 214 918-926. (doi:10.1006/bbrc.1995.2374)

Herman JP, Dolgas CM, Rucker D \& Langub MC Jr 1996 Localization of natriuretic peptide-activated guanylate cyclase mRNAs in the rat brain. Journal of Comparative Neurology 369 165-187. (doi:10.1002/(SICI)10969861(19960527)369:2<165::AID-CNE1 > 3.0.CO;2-1)

Horvath A, Boikos S, Giatzakis C, Robinson-White A, Groussin L, Griffin KJ, Stein E, Levine E, Delimpasi G, Hsiao HP et al. 2006 A genome-wide scan identifies mutations in the gene encoding phosphodiesterase 11A4 (PDE11A) in individuals with adrenocortical hyperplasia. Nature Genetics 38 794-800. (doi:10.1038/ng1809)

Horvath A, Korde L, Greene MH, Libe R, Osorio P, Faucz FR, Raffin-Sanson ML, Tsang KM, Drori-Herishanu L, Patronas Y et al. 2009 Functional phosphodiesterase 11A mutations may modify the risk of familial and bilateral testicular germ cell tumors. Cancer Research 69 5301-5306. (doi:10.1158/0008-5472.CAN-09-0884)

Hu X, Li T, Zhang C, Liu Y, Xu M, Wang W, Jia Z, Ma K, Zhang Y \& Zhou C 2011 GATA4 regulates ANF expression synergistically with $\mathrm{Sp} 1$ in a cardiac hypertrophy model. Journal of Cellular and Molecular Medicine 15 1865-1877. (doi:10.1111/j.1582-4934.2010. 01182.x)

Hyodo S, Kawakoshi A, Bartolo RC, Takei Y, Toop T \& Donald JA 2006 Extremely high conservation in the untranslated region as well as the coding region of CNP mRNAs throughout elasmobranch species. General and Comparative Endocrinology 148 181-186. (doi:10.1016/ j.ygcen.2006.02.014)

Kaiser UB, Halvorson LM \& Chen MT 2000 Sp1, steroidogenic factor 1 (SF-1), and early growth response protein 1 (egr-1) binding sites form a tripartite gonadotropin-releasing hormone response element in the rat luteinizing hormone-beta gene promoter: an integral role for SF-1. Molecular Endocrinology 14 1235-1245. (doi:10.1210/me.14.8.1235)
Kleinert H, Wallerath T, Euchenhofer C, Ihrig-Biedert I, Li H \& Förstermann U 1998 Estrogens increase transcription of the human endothelial NO synthase gene: analysis of the transcription factors involved. Hypertension 31 582-588.

Komatsu Y, Nakao K, Suga S, Ogawa Y, Mukoyama M, Arai H, Shirakami G, Hosoda K, Nakagawa O, Hama N et al. 1991 C-type natriuretic peptide (CNP) in rats and humans. Endocrinology 129 1104-1106. (doi:10.1210/ endo-129-2-1104)

Konrad EM, Thibault G \& Schriffen EL 1992 Autoradiographic visualization of the natriuretic peptide receptor-B in rat tissues. Regulatory Peptides 39 177-189. (doi:10.1016/0167-0115(92)90539-7)

Kotera J, Fujishige K, Imai Y, Kawai E, Michibata H, Akatsuka H, Yanaka N \& Omori K 1999 Genomic origin and transcriptional regulation of two variants of cGMP-binding cGMP-specific phosphodiesterases. European Journal of Biochemistry 262 866-873. (doi:10.1046/j.1432-1327.1999.00450.x)

Kumar P, Garg R, Bolden G \& Pandey KN 2010 Interactive roles of Ets-1, Sp1, and acetylated histones in the retinoic acid-dependent activation of guanylyl cyclase/atrial natriuretic peptide receptor-A gene transcription. Journal of Biological Chemistry 285 37521-37530. (doi:10.1074/jbc.M110.132795)

Liang F, Schaufele F \& Gardner DG 1999 Sp1 dependence of natriuretic peptide receptor A gene transcription in rat aortic smooth muscle cells. Endocrinology 140 1695-1701. (doi:10.1210/en.140.4.1695)

McArdle CA \& Poch A 1992 Dependence of gonadotropinreleasing hormone-stimulated luteinizing hormone release upon intracellular $\mathrm{Ca}_{2}{ }^{+}$pools is revealed by desensitization and thapsigargin blockade. Endocrinology 130 3567-3574.

McArdle CA, Poch A \& Käppler K 1993 Cyclic guanosine monophosphate production in the pituitary: stimulation by C-type natriuretic peptide and inhibition by gonadotropinreleasing hormone in alpha T3-1 cells. Endocrinology 132 2065-2072.

McArdle CA, Ivell R, Kappler K, Muller D, Schmidt C, Poch A \& Kratzmeier M 1994 Production and action of C-type natriuretic peptide in the gonadotrope-derived T3-1 cell line. Endocrine Journal 2 849-856.

Melmed S 2003 Mechanisms for pituitary tumorigenesis: the plastic pituitary. Journal of Clinical Investigation 112 1603-1618.

Minamino N, Aburaya M, Kojima M, Miyamoto K, Kangawa K \& Matsuo H 1993 Distribution of C-type natriuretic peptide and its messenger RNA in rat central nervous system and peripheral tissue. Biochemical and Biophysical Research Communications 197 326-335. (doi:10.1006/ bbrc.1993.2479)

Moncla A, Missirian C, Cacciagli P, Balzamo E, Legeai-Mallet L, Jouve JL, Chabrol B, Le Merrer M, Plessis G, Villard L et al. 2007 A cluster of translocation breakpoints in $2 \mathrm{q} 37$ is associated with overexpression of 
NPPC in patients with a similar overgrowth phenotype. Human Mutation 28 1183-1188. (doi:10.1002/humu. 20611)

Müller D, Hida B, Guidone G, Speth RC, Michurina TV, Enikolopov G \& Middendorff R 2009 Expression of guanylyl cyclase (GC)-A and GC-B during brain development: evidence for a role of GC-B in perinatal neurogenesis. Endocrinology 150 5520-5529. (doi:10.1210/en.2009-0490)

Ohta S, Shimekake Y \& Nagata K 1993 Cell-type-specific function of the $\mathrm{C}$-type natriuretic peptide gene promoter in rat anterior pituitary-derived cultured cell lines. Molecular and Cellular Biology 13 4077-4086.

Pope C, McNeilly JR, Coutts S, Millar M, Anderson RA \& McNeilly AS 2006 Gonadotrope and thyrotrope development in the human and mouse anterior pituitary gland. Developmental Biology 297 172-181. (doi:10.1016/j.ydbio.2006.05.005)

Potter LR, Abbey-Hosch S \& Dickey DM 2006 Natriuretic peptides, their receptors, and cyclic guanosine monophosphate-dependent signaling functions. Endocrine Reviews 27 47-72. (doi:10.1210/er.2005-0014)

Rahmutula D, Cui J, Chen S \& Gardner DG 2004 Transcriptional regulation of type B human natriuretic peptide receptor gene promoter: dependence on $\mathrm{Sp} 1$. Hypertension 44 283-288. (doi:10.1161/01.HYP. 0000136908.60317.92)

Rubinek T, Rubinfeld H, Hadani M, Barkai G \& Shimon I 2005 Nitric oxide stimulates growth hormone secretion from human fetal pituitaries and cultured pituitary adenomas. Endocrine 28 209-216.

Schreiber E, Matthias P, Muller MM \& Schaffner W 1989 Rapid detection of octamer binding proteins with 'mini-extracts', prepared from a small number of cells. Nucleic Acids Research 17 6419. (doi:10.1093/nar/17.15. 6419)

Shimekake Y, Ohta S \& Nagata K 1994 C-type natriuretic peptide stimulates secretion of growth hormone from ratpituitary-derived GH3 cells via a cyclic-GMP-mediated pathway. European Journal of Biochemistry 222 645-650. (doi:10.1111/j.1432-1033.1994.tb18908.x)

Suliman SG, Gurlek A, Byrne JV, Sullivan N, Thanabalasingham G, Cudlip S, Ansorge O \& Wass JA 2007 Nonsurgical cerebrospinal fluid rhinorrhea in invasive macroprolactinoma: incidence, radiological, and clinicopathological features. Journal of Clinical Endocrinology and Metabolism 92 3829-3835. (doi:10.1210/jc.2007-0373)

Tamura N, Doolittle LK, Hammer RE, Shelton JM, Richardson JA \& Garbers DL 2004 Critical roles of the guanylyl cyclase B receptor in endochondral ossification and development of female reproductive organs. PNAS 101 17300-17305. (doi:10.1073/pnas.0407894101)

Thompson IR, Chand AN, Jonas KC, Burrin JM, Steinhelper ME, Wheeler-Jones CP, McArdle CA \& Fowkes RC 2009 Molecular characterisation and functional interrogation of a local natriuretic peptide system in rodent pituitaries, $\alpha \mathrm{T} 3-1$ and L $\beta$ T2 gonadotroph cells. Journal of Endocrinology 203 215-229.

(doi:10.1677/JOE-09-0189)

Turner HE, Nagy Z, Gatter KC, Esiri MM, Harris AL \& Wass JA 2000 Angiogenesis in pituitary adenomas and the normal pituitary gland. Journal of Clinical Endocrinology and Metabolism 85 1159-1162. (doi:10.1210/jc.85.3.1159)

Vesely DL 2009 Cardiac and renal hormones: anticancer effects in vitro and in vivo. Journal of Investigative Medicine 57 22-28.

Wang X, Raulji P, Mohapatra SS, Patel R, Hellermann G, Kong X, Vera PL, Meyer-Siegler KL, Coppola D \& Mohapatra S 2011 Natriuretic peptide receptor A as a novel target for prostate cancer. Molecular Cancer 1056. (doi:10.1186/1476-4598-10-56)

Weck J, Anderson AC, Jenkins S, Fallest PC \& Shupnik MA 2000 Divergent and composite gonadotropin-releasing hormone-responsive elements in the rat luteinizing hormone subunit genes. Molecular Endocrinology 14 472-485. (doi:10.1210/me.14.4.472)

Yanaka N, Kotera J, Ohtsuka A, Akatsuka H, Imai Y, Michibata H, Fujishige K, Kawai E, Takebayashi S, Okumura K et al. 1998 Expression, structure and chromosomal localization of the human cGMP-binding cGMP-specific phosphodiesterase PDE5A gene. European Journal of Biochemistry 255 391-399. (doi:10.1046/j.1432-1327.1998.2550391.x)

Yandle TG, Fisher S, Espiner EA \& Richards AM 1993 The ovine hypothalamus and pituitary have markedly different distributions of C-type natriuretic peptide forms. Peptides 14 713-716. (doi:10.1016/0196-9781(93)90102-M)

Zhan X \& Desiderio DM 2004 The human pituitary nitroproteome: detection of nitrotyrosyl-proteins with two-dimensional western blotting, and amino acid sequence determination with mass spectrometry. Biochemical and Biophysical Research Communications 325 1180-1186. (doi:10.1016/j.bbrc.2004.10.169)

Received in final form 15 May 2012 Accepted 29 May 2012 Made available online as an Accepted Preprint 29 May 2012 